\title{
Effects of switchgrass cultivars and intraspecific differences in root structure on soil carbon inputs and accumulation
}

Jaron Adkins ${ }^{1}$, Julie D. Jastrow ${ }^{2}$, Geoffrey P. Morris ${ }^{3}$, Johan $\mathrm{Six}^{4}$, Marie-Anne de Graaff ${ }^{1}$

${ }^{1}$ Department of Biological Sciences, Boise State University, Boise, ID 83725; ${ }^{2}$ Biosciences

Division, Argonne National Laboratory, Argonne, IL 60439; ${ }^{3}$ Department of Agronomy, Kansas

State University, Manhattan KS, 66506; ${ }^{4}$ Department of Environmental Systems Science, Swiss

Federal Institute of Technology, ETH-Zurich, 8092 Zurich, Switzerland

Correspondence: Jaron Adkins

Department of Biological Sciences

Boise State University

1910 University Drive

Boise ID, 83725-1515

jaronadkins@gmail.com

$+1208-869-4374$

Key words: switchgrass cultivars, root structure, specific root length, soil carbon, carbon-13, $\mathrm{C}_{4}$ grasses 


\section{Introduction}

The search for new sources of sustainable energy has cast attention on cellulose-derived ethanol as a potential fuel, and switchgrass (Panicum virgatum L.), which is rich in lignocellulosic tissues (Lynd et al., 1991), has shown promise as a cellulosic biofuel feedstock (Schmer et al. 2008). Switchgrass is a fast growing, perennial prairie grass common to the Great Plains and eastern states. It is projected that more than 16.9 Mha of land could be dedicated to switchgrass production, yielding 158 dry $\operatorname{Tg~}^{-1}$ (McLaughlin et al., 2002), with a mean net energy yield of $60 \mathrm{GJ} \cdot \mathrm{ha}^{-1} \mathrm{y}^{-1}$ (Schmer et al., 2008). If biofuel production is carbon (C) negative (i.e., the amount of $\mathrm{C}$ sequestered is greater than the amount lost during production, harvest, and transport to a production facility), then, in addition to serving as a renewable energy source, biofuel crops can contribute to climate change mitigation by removing excess $\mathrm{C}$ from the atmosphere (Tilman et al., 2006).

Soil plays an important role in achieving the aim of $\mathrm{C}$ negative bioenergy production because soil can stabilize and sequester large amounts of plant-derived C (Lal, 2004a; b). Carbon sequestration refers to the removal of $\mathrm{C}$ from the atmosphere and the storage of this $\mathrm{C}$ in long term pools (Lal, 2004a; b). Mechanisms that promote soil C sequestration include increased C inputs, stabilization of soil C (both new inputs and existing C), and placement of $\mathrm{C}$ in deeper soil layers (Lal and Kimble, 1997). Thus, plant traits that mediate soil C inputs and soil C stabilization have important impacts on soil $\mathrm{C}$ sequestration. Compared to soils cultivated with annual crops, perennial grassland soils are characterized by high $\mathrm{C}$ accumulation rates (Jobbagy and Jackson, 2000; Conant et al., 2001; Jones and Donnelly, 2004; Soussana et al., 2010). This can be attributed to perennial grasses contributing greater amounts of root-derived $\mathrm{C}$ to soil and 
eliminating the need for annual tillage (Paustian et al., 2000; Jones and Donnelly, 2004; Rees et al., 2005; Jastrow et al., 2007). Thus, grasslands managed for biofuel production may enhance soil $\mathrm{C}$ accumulation by increasing the amount and retention of plant root-mediated soil $\mathrm{C}$ inputs compared to annual cropping systems (Post and Kwon, 2000; Conant et al., 2001; Jones and Donnelly, 2004; Soussana et al., 2010).

Switchgrass in particular contributes a substantial amount of $\mathrm{C}$ inputs to the soil $\mathrm{C}$ pool (McLaughlin and Kszos, 2005; Tilman et al., 2006). McLaughlin and Kszos (2005) estimated average soil $\mathrm{C}$ accumulation rates under switchgrass plots to be as high as $0.78 \mathrm{Mg} \mathrm{Cha}^{-1} \mathrm{y}^{-1}$ in regions across the eastern U.S. The positive impact of switchgrass on soil organic $\mathrm{C}$ stores can be attributed to its extensive root system. Switchgrass roots remain alive after harvest of the feedstock and can penetrate as deep as $3.4 \mathrm{~m}$ (Weaver and Darland, 1949). Since plant roots are one of the primary conduits for transporting photosynthetically fixed $\mathrm{C}$ to the soil (Norby and Jackson, 2000; Rasse et al., 2005; Kong and Six, 2010), these extensive root systems likely strengthen the ability of switchgrass to sequester soil $\mathrm{C}$ by affecting the magnitude and depth of soil C inputs. Switchgrass root systems are most prominent in surface soil, with roots in the top $30 \mathrm{~cm}$ comprising from $66 \%$ to greater than $80 \%$ of the total root mass quantified to $90 \mathrm{~cm}$ (Garten et al., 2010; Garten et al., 2011; Ma et al., 2000), with the greatest proportion of switchgrass root biomass occurring in the top 10-15 cm of soil (Frank et al., 2004; Ma et al., 2000). This indicates that root-derived $C$ inputs will be most prominent in the uppermost soil layers, especially in early establishment years. Switchgrass cultivars have been shown to differentially affect soil C cycling (de Graaff et al., 2014), but root traits that maximize C inputs 
and stabilization, and thereby increase the potential for soil $\mathrm{C}$ sequestration, have not been well identified.

Intraspecific variations in root morphologies among switchgrass cultivars have the potential to impact soil C inputs and C stabilization. Switchgrass cultivars exhibit a range of root phenotypes; for example, specific root lengths (SRL; $\mathrm{m} \mathrm{g}^{-1}$ root mass) can vary by a factor of five among cultivars (de Graaff et al., 2013; de Graaff et al., 2014). Such phenotypic variation may have consequences for the $\mathrm{C}$ sequestration potential of different cultivars (Schweitzer et al., 2004; Whitham et al., 2006; Lojewski et al., 2012). Root systems with a low SRL feature a greater abundance of large diameter, longer-lived roots, which are rich in slowly decomposing cellulose and lignins (Guo et al., 2004). Conversely, root systems with a high SRL have a relatively large abundance of small diameter, ephemeral, and easily decomposed roots with high concentrations of nitrogen and labile C compounds (Norby and Jackson, 2000; Guo et al., 2004). Microbes are able to use plant tissues with high concentrations of $\mathrm{N}$ and labile $\mathrm{C}$ compounds more efficiently than tissues with low $\mathrm{N}$ and more recalcitrant $\mathrm{C}$ chemistry, and, as a result, labile $\mathrm{C}$ may be preferentially stabilized in soil as microbial residues (Gentile et al., 2011a; Gentile et al., 2011b; Cotrufo et al., 2013). Fine roots may also exhibit more root exudation on a root weight basis, increasing the concentration of compounds that are easily utilized by soil microbes (Norby et al., 1987; Xu and Juma, 1994; Jaeger et al., 1999; Paterson and Sim, 1999). Due to the greater abundance of $\mathrm{N}$ and labile $\mathrm{C}$ in fine roots compared to coarse roots, SRL may serve as a useful proxy for identifying switchgrass cultivars that might maximize soil C inputs.

Soil organic matter can be characterized by particle size, which provides information about the transformation state and potential long-term fate and stability of the $\mathrm{C}$ associated with 
each particle size fraction. Coarse particulate organic matter $(\mathrm{CPOM} ; \geq 250 \mu \mathrm{m})$ and fine particulate organic matter (FPOM; 53-250 $\mu \mathrm{m})$ mostly consist of partially decomposed plant residues and microbial debris (Hassink et al., 1997; Six et al., 2002). Carbon associated with siltsized particles $(2-53 \mu \mathrm{m})$ is composed mainly of aromatic plant compounds (Christensen, 2001). The $\mathrm{C}$ associated with the clay-sized fraction $(\leq 2 \mu \mathrm{m})$ is derived primarily from the metabolic byproducts of microbial decomposition (Christensen, 2001). Carbon associated with the silt- and clay-sized fractions is generally considered to be more stable because it consists of more decomposed and humified material that is physically and chemically protected via association with organomineral complexes (Six et al., 2002). Consequently, the silt- and clay-sized fractions have more long-term $\mathrm{C}$ sequestration potential than the coarser POM fractions (Christensen, 2001). Garten and Wullschleger (2000) assessed soil C dynamics under switchgrass stocks and found that $\mathrm{C}$ associated with the mineral fraction (the combination of the silt- and clay-sized fractions) had turnover times ranging from 26 to 40 years, whereas POM associated $\mathrm{C}(>53 \mu \mathrm{m})$ had turnover times ranging from 2.6 to 4.3 years. Hence, if switchgrass cultivars vary in the amount or rate of $\mathrm{C}$ inputs to silt- and clay-sized fractions, identifying cultivars and traits that can maximize $\mathrm{C}$ inputs to these fractions could have important implications for enhancing the $\mathrm{C}$ sequestration potential of switchgrass as a bioenergy crop.

The aim of this study was to assess how different switchgrass cultivars impact soil C inputs, whether these impacts vary with depth, and whether SRL explains these impacts. We hypothesized that root systems with higher SRL would exhibit greater C inputs due to a greater surface area of fine root tips that contribute to exudation and more frequent turnover (Czarnota et al., 2003; Nguyen, 2003; Piñeros et al., 2002). Switchgrass is a $\mathrm{C}_{4}$ plant, and the cultivars we 
used for this study had been grown for 27 months on soils previously dominated by $\mathrm{C}_{3}$ grasses, resulting in different natural abundance $\delta^{13} \mathrm{C}$ values for the plant material and soils. The difference in isotopic values between plants and soils allowed us to quantify plant-derived C inputs to CPOM, FPOM, silt-, and clay-sized fractions.

\section{Methods}

\subsection{Experimental Design and Sampling protocol}

In the fall of 2007, standing vegetation (a mixture of the perennial, cool-season $\mathrm{C}_{3}$ grasses) in a 5.4-ha field at the U.S. Department of Energy National Environmental Research Park at Fermilab in Batavia, IL, USA $\left(88^{\circ} 13^{\prime} 47^{\prime \prime} \mathrm{W}, 41^{\circ} 50^{\prime} 29^{\prime \prime} \mathrm{N}\right)$ was treated with herbicide and removed by burning. The following spring, vegetative regrowth was suppressed with another herbicide treatment. In June 2008, Panicum virgatum L. (hereafter: switchgrass) ecotypes originating from different latitudes were planted as a replicated field trial. Monocultures of 17 switchgrass cultivars were sown from seed in $2 \times 3 \mathrm{~m}$ or $2 \times 1 \mathrm{~m}$ replicated field plots $(\mathrm{n}=4)$ in a randomized block design on soils that had supported the stand of $\mathrm{C}_{3}$ cool season grasses for 36 years. The soil at the site is Grays silt loam (Fine-silty, mixed, superactive, mesic Mollic Oxyaquic Hapludalf). In October 2010, we collected soils from six switchgrass cultivars using a 4.8-cm diameter soil corer. Each sample was collected from on top of the crown of one individual from each of four replicate plots to a depth of $30 \mathrm{~cm}$. The selected cultivars included: (1) Alamo, (2) Kanlow, (3) Carthage, (4) Cave-in-Rock, (5) Forestburg, and (6) Blackwell. For the purpose of obtaining a reference measurement for soil $\mathrm{C}$ content and natural abundance of stable $\mathrm{C}$ isotopic signatures, three soil cores were also collected from an adjacent area of Grays silt loam that remained in $\mathrm{C}_{3}$ 
cool season grasses (mainly Bromus inermis Leyss., Elymus repens (L.) Gould, and Poa spp.). Upon collection, all cores were divided into $10 \mathrm{~cm}$ increments. The cores were shipped to Boise State University and kept at $6^{\circ} \mathrm{C}$ until further processing. The soils were sieved $(2 \mathrm{~mm})$, rhizomes were removed, and all visible roots were hand-picked from the soil. All roots collected from each depth increment were washed in deionized water and analyzed for root length using WinRhizo (Regents Instruments, Inc.). After root length determinations, the roots were dried at $70^{\circ} \mathrm{C}$ and weighed, and SRL was calculated as total root length divided by total root dry weight for each depth increment (de Graaff et al., 2014). One Forestburg sample and one Cave-in-Rock sample, both from the 0-10 cm depth increment, were missing and were not included in any analyses.

\subsection{Soil Fractionation}

Subsamples of soil from each plot and from each of the three depth increments were sizefractionated to separate CPOM (>250 $\mu \mathrm{m})$, FPOM $(53-250 \mu \mathrm{m})$, silt-sized $(2-53 \mu \mathrm{m})$, and claysized $(<2 \mu \mathrm{m})$ fractions using a procedure adapted from Cambardella and Elliott (1992). Subsamples (12.6-12.8 g) of the 2-mm sieved soil were oven dried at $65^{\circ} \mathrm{C}$, and then dispersed by shaking overnight on a reciprocating shaker in $40 \mathrm{~mL}$ of $5 \mathrm{~g} \mathrm{~L}^{-1}$ sodium hexametaphosphate (NaHMP) solution. The dispersed soil solution was rinsed through a $250 \mu \mathrm{m}$ sieve to collect the CPOM fraction, and then rinsed through a $53 \mu \mathrm{m}$ sieve to collect the FPOM fraction. Both fractions were transferred to aluminum pans for drying. The solution that passed through the sieves contained both the silt-sized (hereafter referred to as silt) and clay-sized (hereafter referred to as clay) fractions. This solution was centrifuged for $1 \mathrm{~min}$. and $22 \mathrm{sec}$ at $270 \mathrm{RCF}$ and $20^{\circ} \mathrm{C}$ in a Sorvall Legend X1R centrifuge fitted with a swinging bucket rotor. The clay-containing 
supernatant was pipetted into another centrifuge tube, and the silt pellet was transferred to an aluminum pan for drying. The clay-containing solution was then flocculated with $10 \mathrm{~mL}$ of $0.25 \mathrm{M} \mathrm{CaCl}_{2}+\mathrm{MgCl}_{2}$ solution and centrifuged for $10 \mathrm{~min}$ at $2000 \mathrm{RCF}$ and $20^{\circ} \mathrm{C}$ in the Sorvall Legend X1R centrifuge. After discarding the supernatant, the clay pellet was transferred to an aluminum pan for drying. The CPOM, FPOM, silt, and clay fractions were oven dried $\left(65^{\circ} \mathrm{C}\right)$ and stored in glass scintillation vials. Total mass recovery of the fractions averaged $98.6 \pm 0.002$ $\%(\mathrm{SE} ; \mathrm{n}=70)$.

\subsection{Isotope Analysis}

Dried subsamples of each bulk soil and soil fraction were ground to a fine powder, wrapped in tin capsules, and analyzed for total $\mathrm{C}$ and stable $\mathrm{C}$ isotope ratios $\left({ }^{13} \mathrm{C} /{ }^{12} \mathrm{C}\right)$ on a Thermo Delta $\mathrm{V}$ Plus isotope ratio mass spectrometer (IRMS) coupled with a Costech Elemental Analyzer in continuous flow mode. Total soil $\mathrm{C}$ was equivalent to soil organic $\mathrm{C}$ because no carbonates were present in these soils. After fractionation, the remaining bulk soil from nine of the samples was insufficient for analysis of total bulk soil $\mathrm{C}$, so total soil $\mathrm{C}$ concentrations for all samples were derived from the summation of individual fractions. C recovery in the fractions (based on samples where bulk soil could be analyzed directly) averaged $95.6 \pm 1.4 \%(\mathrm{SE} ; \mathrm{n}=62)$.

Results of the $\mathrm{C}$-isotope analyses were expressed as $\delta^{13} \mathrm{C}$. The ${ }^{13} \mathrm{C}$ values were determined in relation to Vienna-Pee Dee Belemnite as follows:

$\delta^{13} \mathrm{C}=\left(\left(\mathrm{R}_{\text {sample }} / \mathrm{R}_{\text {standard }}\right)-1\right) * 1000$ (Eq. 1) 
where $\mathrm{R}$ is the stable $\mathrm{C}$ isotope ratio.

To calculate the amount of root-derived $\mathrm{C}$ present in bulk soil and each soil fraction, the following mass balance was used (Cheng, 1996; Nottingham et al., 2009):

$\mathrm{Q}_{\mathrm{p}}=\mathrm{Q}_{\mathrm{t}} *\left(\delta^{13} \mathrm{C}_{\mathrm{t}}-\delta^{13} \mathrm{C}_{\mathrm{s}}\right) /\left(\delta^{13} \mathrm{C}_{\mathrm{p}}-\delta^{13} \mathrm{C}_{\mathrm{s}}\right)$

(Eq. 2)

where $Q_{t}$ is the total amount of soil $C, \delta^{13} C_{t}$ is its isotopic composition, $Q_{p}$ is the amount of soil C derived from switchgrass root material, $\delta^{13} C_{p}$ is the isotopic composition of the switchgrass root material $(-12.4 \%$ \pm 0.21$)$ (de Graaff et al., 2013), and $\delta^{13} \mathrm{C}_{\mathrm{s}}$ is the isotopic composition of the adjacent $\mathrm{C}_{3}$ grassland soil. The calculation of $\mathrm{Q}_{\mathrm{p}}$ for each soil fraction at each depth increment was based on the measured value of $\delta^{13} \mathrm{C}_{\mathrm{s}}$ for the corresponding fraction and depth increment.

Due to isotopic dilution, we were unable to detect switchgrass-derived $\mathrm{C}$ in the bulk soil. As a result, total switchgrass-derived $\mathrm{C}$ was calculated according to the following formula:

$\mathrm{Q}_{\mathrm{b}}=\mathrm{A}_{\mathrm{CPOM}} * \mathrm{Q}_{\mathrm{p}(\mathrm{CPOM})}+\mathrm{A}_{\mathrm{FPOM}} * \mathrm{Q}_{\mathrm{p}(\mathrm{FPOM})}+\mathrm{A}_{\text {silt }} * \mathrm{Q}_{\mathrm{p}(\text { silt })}+\mathrm{A}_{\text {clay }} * \mathrm{Q}_{\mathrm{p}(\text { clay })}$

where $\mathrm{Q}_{\mathrm{b}}$ is total $\mathrm{C}$ derived from switchgrass material in the bulk soil, $\mathrm{A}_{\text {fraction }}$ is the relative abundance (proportional mass) of the respective soil fractions, and $\mathrm{Q}_{\mathrm{p} \text { (fraction) }}$ is the amount of soil 
C derived from switchgrass root material in the respective soil fractions, as calculated using Eq.

2. For the calculation of $\mathrm{Q}_{\mathrm{b}}$ for each sample, if switchgrass root-derived $\mathrm{C}$ was not detected in $\mathrm{a}$ fraction, then a value of 0 was assigned to $\mathrm{Q}_{\mathrm{p}}$ for that fraction.

\subsection{Statistical Analysis}

To assess overall effects of switchgrass cultivars on soil C, multivariate analysis of variance (MANOVA) was conducted with cultivar identity as a fixed effect and either total soil C, total switchgrass-derived soil $\mathrm{C}$, or $\delta^{13} \mathrm{C}$ at the three depth increments as dependent variables (using the Multivariate General Linear Model in SPSS Statistics 19.0).

To assess whether the relative impact of switchgrass cultivars on total soil C, switchgrass-derived soil $\mathrm{C}$, and $\delta^{13} \mathrm{C}$ followed similar patterns across depth increments (e.g., cultivar "a" has higher soil C than cultivar "b" and both are greater than cultivar "c" etc., at all depth increments), profile analyses were performed with cultivar identity as the between-subjects factor and $\mathrm{C}$ values at different depths as the within-subjects variable (using the Repeated Measures General Linear Model in SPSS Statistics 19.0). A significant interaction between cultivar and $\mathrm{C}$ value indicates that the relative impact of cultivars varies with depth. When the assumption of equal covariance was met, we assessed differences using the Pillai's Trace, Wilks' Lambda, Hotelling's Trace and Roy's Largest Root tests, and when the assumption of equal covariance was not met, we used the Greenhouse-Geisser test. When the MANOVA or repeated measures analysis was found to be significant, one-way analysis of variance (ANOVA) was used to assess differences in total soil $\mathrm{C}$, switchgrass-derived soil $\mathrm{C}$, and $\delta^{13} \mathrm{C}$ among cultivars independently for each of the three depth increments (using the Univariate General Linear Model 
in SPSS Statistics 19.0). The ANOVAs were conducted with cultivar as a fixed effect. For all ANOVAs, means were compared by the Tukey test. The level of significance for all statistical tests was $\alpha \leq 0.05$.

To assess the relationship between root traits and switchgrass-derived $\mathrm{C}$, we calculated Pearson product-moment correlations $(r)$ between switchgrass-derived C and SRL or root biomass. The significance threshold was $\alpha \leq 0.05$.

\section{Results}

\subsection{Total Soil C}

Soil C concentrations differed significantly among cultivars for bulk soils (Fig. 1). At the 0-10 cm depth there was a $40 \%$ difference between the cultivars with the highest (Forestburg) and lowest (Carthage) soil C values (Fig. 1a). Forestburg had a significantly higher bulk soil C concentration than Carthage and Alamo ( $\mathrm{p} \leq 0.01$; Fig. 1a). Cave-in-Rock had significantly higher bulk soil $\mathrm{C}$ concentrations than Carthage ( $\mathrm{p} \leq 0.01$; Fig. 1a). At the $10-20 \mathrm{~cm}$ depth, soil C concentration associated with Cave-in-Rock was significantly higher than for any of the other cultivars. Cave-in-Rock soil C concentration was $70 \%$ greater than Carthage, which had the lowest soil C concentration ( $\mathrm{p} \leq 0.001$; Fig. $1 \mathrm{~b}$ ). At the $20-30 \mathrm{~cm}$ depth, there were no significant differences in soil C concentrations among cultivars (Fig. 1c). Repeated measures profile analysis showed that the relative impact of different cultivars on total soil $\mathrm{C}$ concentration did not vary significantly with depth. Analyses of soils collected in 2008, shortly after planting 
of the switchgrass cultivars, indicated that initial soil $\mathrm{C}$ concentrations were statistically similar (data not shown).

Significant differences in soil fraction C concentrations were also found within fractions among cultivars at all depths (Table 1), although when $\mathrm{C}$ concentrations were weighted by relative fractional abundance (i.e. C content; Fig. 1a, 1b, and 1c), only the $\mathrm{C}$ content in the silt fractions was significantly different among cultivars (i.e. when concentration is expressed as fraction percent $\mathrm{C}$, there were differences among all fractions, but when expressed as $\mathrm{C}$ content in $\mathrm{mg} \mathrm{C} \mathrm{g}^{-1}$ soil only silt $\mathrm{C}$ differed among cultivars). At the $0-10 \mathrm{~cm}$ depth, there were significant differences in CPOM, FPOM, and silt percent $\mathrm{C}$ among cultivars. Forestburg and Cave-in-Rock had lower CPOM percent $C$ than Carthage ( $\leq \leq 0.05$; Table 1$)$. Kanlow and Cavein-Rock had lower FPOM percent $\mathrm{C}$ than Alamo and Carthage, and Blackwell had lower FPOM percent $\mathrm{C}$ than Carthage $(\mathrm{p} \leq 0.001$; Table 1). Carthage had a lower silt percent $\mathrm{C}$ than Forestburg and Cave-in-Rock ( $\mathrm{p} \leq 0.01$; Table 1$)$. When expressed as $\mathrm{mg} \mathrm{C} \mathrm{g}^{-1}$ soil, only silt $\mathrm{C}$ content differed among cultivars, where Cave-in-Rock had more silt C than Carthage.

At the 10-20 cm depth, Alamo had greater CPOM and FPOM percent C than Blackwell, Kanlow, and Forestburg ( $\mathrm{p} \leq 0.01$; Table 1). Cave-in-Rock had significantly greater silt percent C than Carthage, Alamo, Kanlow, and Forestburg; Blackwell had significantly greater silt percent $\mathrm{C}$ than Carthage $(\mathrm{p} \leq 0.001$; Table 1). Carthage had lower percent clay $\mathrm{C}$ than Cave-inRock ( $\mathrm{p} \leq 0.01$; Table 1$)$. When expressed as $\mathrm{mg} \mathrm{C} \mathrm{g}^{-1}$ soil, only silt $\mathrm{C}$ content differed among cultivars, where Cave-in-Rock and Blackwell had greater silt $\mathrm{C}$ than Carthage $(\mathrm{p} \leq 0.001)$.

At the 20-30 cm depth, there were significant differences in $\mathrm{C}$ concentrations among the CPOM, FPOM, and clay fractions. Alamo had greater CPOM percent $\mathrm{C}$ than all other cultivars 
except Carthage ( $\mathrm{p} \leq 0.001$; Table 1). Alamo and Carthage had greater FPOM percent $\mathrm{C}$ than all other cultivars except Cave-in-Rock ( $\mathrm{p} \leq 0.001$; Table 1). Blackwell, Carthage, and Alamo had lower clay percent $\mathrm{C}$ than Cave-in-Rock ( $\mathrm{p} \leq 0.01$; Table 1$)$. When expressed as $\mathrm{mg} \mathrm{C}^{-1}$ soil, there were no significant differences in fraction C content at the 20-30 cm depth.

\subsection{Switchgrass-derived Soil C}

The differences in $\delta^{13} \mathrm{C}$ signatures between the $\mathrm{C}_{4}$ plants (i.e., switchgrass cultivars) and the $\mathrm{C}_{3}$ soils allowed us to quantify the amount of switchgrass-derived $\mathrm{C}$ in the soil. The $\delta^{13} \mathrm{C}$ values measured for bulk soils and for CPOM, FPOM, silt, and clay fractions from the experimental plots and from the adjacent $\mathrm{C}_{3}$ grassland are shown in Table 2. We confirmed that the CPOM fractions of samples in $\mathrm{C}_{3}$ grassland soils had a $\delta^{13} \mathrm{C}$ signature characteristic of $\mathrm{C}_{3}$ plants. In the $\mathrm{C}_{3}$ grassland soils, the $\delta^{13} \mathrm{C}$ signatures of the other soil fractions increased (i.e., became more enriched with ${ }^{13} \mathrm{C}$ ) as particle size of the fractions decreased. . The ${ }^{13} \mathrm{C}$ enrichment of the FPOM, silt, and clay fractions from the $\mathrm{C}_{3}$ grassland soils may still in-part reflect historical land use conditions, which consisted of $\mathrm{C}_{4}$-dominated tallgrass prairie converted to various crops, including corn production, prior to the establishment of cool-season $\mathrm{C}_{3}$ grasslands 36 years before switchgrass seeding. . The bulk soil and all fractions also showed increasing ${ }^{13} \mathrm{C}$ enrichment with depth. The $\delta^{13} \mathrm{C}$ signatures of the bulk soils and FPOM, silt, and clay fractions from the experimental plots were not significantly different from those of the adjacent $\mathrm{C}_{3}$ dominated field. Only the $\delta^{13} \mathrm{C}$ values of the CPOM fractions were significantly enriched with ${ }^{13} \mathrm{C}$ in the experimental plots compared to the reference plot, and this was consistent at all depths. 
Switchgrass-derived soil C differed significantly among cultivars. These differences occurred at the 0-10 depth increment, but not at the other depth increments (Figs. 1d, 1e, and 1f), and repeated measures tests showed that there were no significant changes in relative cultivar impacts on switchgrass-derived $\mathrm{C}$ across depths. At the $0-10 \mathrm{~cm}$ depth, Blackwell contributed $61 \%$ more switchgrass-derived $\mathrm{C}$ than Alamo ( $\mathrm{p} \leq 0.05$; Fig. 1d). Although cultivar differences of $64 \%$ and $54 \%$ occurred between the high and low values of switchgrass-derived $\mathrm{C}$ at the 10 20 and 20-30 cm depths, respectively, these differences were not statistically significant (Fig. 1e and 1f). No significant cultivar differences in switchgrass-derived $\mathrm{C}$ were found for any of the individual soil fractions.

\subsection{Linking Root Biomass and Specific Root Length to Soil C}

Standing root biomass and root $\mathrm{C}$ concentrations were reported previously, and no significant differences in root biomass or root $\mathrm{C}$ concentrations among cultivars were found (de Graaff et al., 2014). However, SRL differed significantly among cultivars at all depths (de Graaff et al., 2013; de Graaff et al., 2014). Correlations between root biomass and switchgrass-derived soil C were not significant. Similarly, the relationships between SRL and switchgrass-derived C were not significant at depths of 10-20 and 20-30 cm, nor was the correlation at the 0-10 cm depth when all points were included in the analysis (Fig. $2 ; r=0.34, \mathrm{p}=0.12$ ). However, switchgrassderived C and SRL were positively correlated at the $0-10 \mathrm{~cm}$ depth when one Forestburg point was excluded (Fig. 2; $r=0.61, \mathrm{p} \leq 0.01$ ). Switchgrass-derived $\mathrm{C}$ in this plot was consistently low across fractions, with CPOM, FPOM, and clay fractions exhibiting switchgrass-derived $\mathrm{C}$ that was, respectively, $45 \%, 57 \%$, and $87 \%$ lower than the averages of all other plots. This plot also 
exhibited total $\mathrm{C}$ concentrations in the CPOM and FPOM fractions that were, respectively, 52\% and $20 \%$ lower than the average of all other plots, and the plot was less enriched in $\delta^{13} \mathrm{C}$ in the clay fraction compared to the average of all other plots (-20.88\%o vs $-19.84 \%$ o).

\section{Discussion}

With this study, we asked whether six switchgrass cultivars differentially impact soil C inputs and stability and whether differences in root structure can account for these differences. The study led to two main results: (1) soil C concentrations at $0-10 \mathrm{~cm}$ and $10-20 \mathrm{~cm}$ depths varied significantly among switchgrass cultivars, and (2) switchgrass-derived soil C differed significantly among cultivars at the $0-10 \mathrm{~cm}$ depth. In addition, we found some evidence to suggest that a positive relationship might exist between SRL and switchgrass-derived soil C at the $0-10 \mathrm{~cm}$ depth when one potential outlier data point was excluded (Fig. $2 ; r=0.61, \mathrm{p} \leq 0.01$ ).

The cultivars that exhibited the greatest bulk soil $\mathrm{C}$ concentrations tended to also exhibit the greatest $\mathrm{C}$ concentrations in the mineral fractions, but among the lowest $\mathrm{C}$ concentrations in the POM fractions (Figs. 1a, 1b, 1c). Additionally, the cultivar with the lowest bulk soil C concentration at $0-10 \mathrm{~cm}$ (Carthage) exhibited the highest CPOM-C concentration at this depth.These results suggest that cultivars that most effectively accumulate soil C do so by incorporating new or existing $\mathrm{C}$ into mineral fractions quickly, while cultivars that are less effective at soil $\mathrm{C}$ accumulation tend to exhibit relatively greater POM-C concentrations. Although these results suggest that variations in plant derived-C inputs associated with different cultivars might impact soil C concentrations, we cannot discount the possibility that observed differences were related to chance variations in initial soil $\mathrm{C}$ due to existing spatial heterogeneity across the field when the experiment was established. 
We were able to use natural abundance stable $\mathrm{C}$ isotopes to more definitively track cultivar differences in $\mathrm{C}_{4}-\mathrm{C}$ inputs derived from switchgrass to soil organic matter characterized by a strong $\mathrm{C}_{3}$-derived $\delta^{13} \mathrm{C}$ signature in the CPOM fractions (Table 2). As seen in other studies, the increasingly ${ }^{13} \mathrm{C}$-enriched isotopic signatures of the FPOM, silt, and clay fractions were likely due in large part to isotopic fractionation during decomposition (Desjardins et al., 1994; Gerzabek and Haberhauer, 2001; Jolivet et al., 2003). Similarly, depth-related isotopic enrichment has been commonly reported (van Kessel et al., 2006; Wynn et al., 2006). Initial bulk soil and fraction $\delta^{13} \mathrm{C}$ signatures were still sufficiently different from the $\delta^{13} \mathrm{C}$ of switchgrass biomass to enable mass balance calculations. Further, we accounted for processrelated isotopic fractionation by using fraction- and depth-specific $\delta^{13} \mathrm{C}$ values as the $\mathrm{C}_{3}$-soil endmembers in mass balance calculations.

Only the $\delta^{13} \mathrm{C}$ signatures of the CPOM fractions were consistently and significantly enriched in ${ }^{13} \mathrm{C}$ compared to the adjacent $\mathrm{C}_{3}$-dominated field. The lack of a significant difference in $\delta^{13} \mathrm{C}$ signature between other fractions from the switchgrass plots and $\mathrm{C}_{3}$-dominated field was likely due to the application of herbicide used to remove existing $\mathrm{C}_{3}$-grasses from the experimental plots prior to switchgrass establishment. Pretreatment of these plots caused belowground residues to become a large source of new $\mathrm{C}_{3}$-derived $\mathrm{C}$ inputs to soil at initiation of the experiment. The magnitude of these inputs was likely rather large compared to the amount of $\mathrm{C}_{4}$-derived inputs deposited during the initial 27 months of an establishing switchgrass stand. Thus, isotopic dilution of $\mathrm{C}_{4}$ inputs may have impacted our ability to detect switchgrass-derived inputs in the bulk soils and the soil fractions that are smaller and generally more microbially processed than CPOM. Surprisingly, however, mass balance calculations - which integrate 
variations in both isotopic enrichment and soil $\mathrm{C}$ - revealed that cultivar differences in $\mathrm{C}$ inputs to soil were not attributable to a particular fraction such as CPOM. Rather, cultivar differences were discernable only as cumulative inputs distributed across all fractions, suggesting small rapid turnover pools exist within all particle size fractions (O’Brien et al., 2011; Torn et al., 2013). Inputs to these pools might include root exudates or other soluble $\mathrm{C}$ forms, processed residues of labile rhizodeposits, or deposition of microbial necromass (Grandy and Neff, 2008; Gude et al., 2012).

We found cultivar differences in switchgrass-derived soil $\mathrm{C}$ in the surface $10 \mathrm{~cm}$, where root densities are greatest, suggesting that different cultivars accumulate soil $\mathrm{C}$ at different rates. This contributes to a growing body of evidence that important ecosystem processes related to the soil C cycle are under genetic control (Schweitzer et al., 2004; Lojewiski et al., 2012; Madritch and Hunter, 2002). Interestingly, cultivars associated with the most total soil C (Cave-in-Rock and Forestburg) were not the same cultivars that exhibited the greatest amount of switchgrassderived soil C (Blackwell). This disunity may be caused by differences in input and processing of rhizodeposits. The high total soil $\mathrm{C}$ but relatively low concentrations of $\mathrm{C}$ in the POM fractions associated with Cave-in-Rock and Forestburg could indicate rapid decomposition of root litter, and subsequent sorption of labile $\mathrm{C}$ on mineral surfaces. Alternatively, cultivar differences in phenology might lead to root turnover at times during the growing season when conditions are more favorable to decomposition. For example, Forestburg originates from a more northernly latitude than the other cultivars and it flowers and senesces earlier than the other cultivars at this site (personal observation). Early senescence likely results in Forestburg root turnover and inputs occurring earlier in the growing season, when temperature and moisture 
conditions are more favorable for decomposition, leading to greater $\mathrm{C}$ loss from the CPOM fraction. Additional measurements will be needed to sort out actual long-term effects of different cultivars on soil $\mathrm{C}$ inputs and retention and the mechanisms responsible.

We found some evidence to suggest that differences in switchgrass-derived soil $\mathrm{C}$ were related to root structure. Although, the correlation between SRL and switchgrass-derived C inputs for the six studied cultivars was not significant, visual examination of the data (Fig. 2) suggested that a single outlier was substantially obscuring an otherwise positive relationship. Exclusion of this data point (just one of the Forestburg replicates) from the analysis resulted in a positive correlation between SRL and switchgrass-derived soil C at the 0-10 cm depth (Fig. 2;r $=0.61, \mathrm{p} \leq 0.01)$. The excluded Forestburg data point represented the lowest amount of switchgrass-derived C among all sampled plots and clearly did not fit the trend established by the other data. At the 0-10 $\mathrm{cm}$ depth, the Forestburg plots also exhibited the greatest variability in SRL (de Graaff et al., 2013) and in switchgrass-derived soil C (Fig. 1d). The generally positive relationship between SRL and switchgrass-derived C agrees with our hypothesis that finer root systems enhance soil $\mathrm{C}$ accumulation. Our findings corroborate previous research indicating that switchgrass root characteristics have significant effects on belowground C dynamics (de Graaff et al., 2013).

These results highlight the importance of incorporating additional root structural data such as SRL into soil C cycling research to improve understanding of soil $\mathrm{C}$ input and retention (Wu et al., 2007). Although root biomass is an important indicator of root production, it does not provide any information about the number of root segments that are involved in the exudation process. Greater SRL indicates a greater surface area of root segments per unit biomass, thus 
increasing the surface area of roots from which exudation occurs (Groleau-Renaud et al., 1998;

Darwent et al., 2003; Czarnota et al., 2003; Nguyen, 2003; Piñeros et al., 2002). In addition, smaller diameter roots, which occur in greater quantities in root systems with a greater SRL, tend to turn-over more frequently than roots with a coarser diameter (Guo et al., 2008a, 2008b;

Tierney and Fahey, 2002; Wells and Eissenstat, 2001), thus contributing to overall greater inputs for the same mass of roots. In contrast, fine roots have a significant amount of suberin, relative to the same mass of coarser roots, which can slow down decomposition rates, and may contribute to the retention of root- $\mathrm{C}$ in soil (Goebel et al., 2011).

Land conversion for biofuel production can release a substantial amount of soil C (Fargione et al., 2008). Our findings indicate that switchgrass-derived soil C inputs were substantial even after only 27 months of growth, ranging between $1.2 \mathrm{mg} \mathrm{C} \mathrm{g}^{-1}$ dry soil and 3.2 mg C g ${ }^{-1}$ dry soil at the $0-10 \mathrm{~cm}$ depth (Fig. 1d) and suggesting that any land-conversion induced soil $\mathrm{C}$ losses might be repaid rather quickly. Using the average bulk density of the site to $10 \mathrm{~cm}$ $\left(1.19 \mathrm{~g} \mathrm{~cm}^{-3}\right)$, this equates to between 630 and $1700 \mathrm{~kg} \mathrm{C} \mathrm{ha}^{-1} \mathrm{y}^{-1}$ of switchgrass-derived soil C inputs to a depth of $10 \mathrm{~cm}$, representing between 1.7 and $6.2 \%$ of the $\mathrm{C}$ stocks present in 2010 . All estimates were derived from cores collected directly over the crown of switchgrass plants, so the magnitude is likely inflated at the field scale, as soils from the interspace likely have lower input rates. These results are in agreement with previous research showing that soil $\mathrm{C}$ can accumulate under switchgrass production (McLaughlin and Kszos, 2005; Adler et al., 2007; Garten, 2012).

While we found significant differences in soil C inputs, a model developed by Garten (2012) predicts that rates of soil C sequestration under switchgrass may not reach a steady state 
until ten years after establishment. Moreover, switchgrass might accumulate soil C stocks beyond thirty years (Garten, 2012). Indeed, restored $\mathrm{C}_{4}$-dominated tall-grass prairies—of which switchgrass is a component - have supported linear soil $\mathrm{C}$ accumulation for at least 20 years (Matamala et al., 2008; O'Brien et al., 2010). Our study assessed soil C after 27 months of growth, and cultivar-specific differences might increase, attenuate, or shift over time. Further research is needed to determine how cultivars, root structure, and site-based edaphic differences interact to impact soil $\mathrm{C}$ stabilization and which characteristics promote quicker and/or more sustained rates of $\mathrm{C}$ sequestration.

\section{Acknowledgements}

We thank Xochi Campos for assistance with soil fractionations and Timothy Vugteveen for collecting soil and root samples. This work was supported in part by the U.S. Department of Agriculture National Institute of Food and Agriculture. This work also was supported by the U.S. Department of Energy, Office of Science, Office of Biological and Environmental Research under contract DE-AC02-06CH11357 to Argonne National Laboratory.

\section{References}

Adler, P.R., Del Grosso, S.J., Parton, W.J., 2007. Life-cycle assessment of net greenhouse-gas flux for bioenergy cropping systems. Ecological Applications 17, 675-691.

Bowen G.D., 1968. Chloride efflux along Pinus radiata roots. Nature 218, 686-687.

Cambardella, C.A., Elliott, E.T., 1992. Particulate soil organic-matter changes across a grassland cultivation sequence. Soil Science Society of America Journal 56, 777-783. 
Cheng, W.X., 1996. Measurement of rhizosphere respiration and organic matter decomposition using natural C-13. Plant and Soil 183, 263-268.

Christensen, B.T., 2001. Physical fractionation of soil and structural and functional complexity in organic matter turnover. European Journal of Soil Science 52, 345-353.

Conant, R.T., Paustian, K., Elliott, E.T., 2001. Grassland management and conversion into grassland: Effects on soil carbon. Ecological Applications 11, 343-355.

Cotrufo, M.F., Wallenstein, M.D., Boot, C.M., Denef, K., Paul, E., 2013. The Microbial Efficiency-Matrix Stabilization (MEMS) framework integrates plant litter decomposition with soil organic matter stabilization: do labile plant inputs form stable soil organic matter? Global Change Biology 19, 988-995.

Czarnota, M.A., Paul, R.N., Weston, L.A., Duke, S.O., 2003. Anatomy of SorgoleoneSecreting Root Hairs of Sorghum Species. International Journal of Plant Sciences 164, 861-866

Darwent, M.J., Paterson, E., McDonald, A.J.S., Tomos, A.D., 2003. Biosensor reporting of root exudation from Hordeum vulgare in relation to shoot nitrate concentration. Journal of Experimental Botany 54, 325-334.

De Deyn, G.B., Cornelissen, J.H.C., Bardgett, R.D., 2008. Plant functional traits and soil carbon sequestration in contrasting biomes. Ecology Letters 11, 516-531.

de Graaff, M.A., Classen, A.T., Castro, H.F., 2010. Labile soil carbon inputs mediate the soil microbial community composition and plant residue decomposition rates. New Phytologist 188, $1055-1064$ 
de Graaff, M.A., Jastrow, J.D., Gillette, S., Johns, A., Wullschleger, S.D., 2014. Differential priming of soil carbon driven by soil depth and root impacts on carbon availability. Soil Biology \& Biochemistry 69, 147-156.

de Graaff, M.A., Six, J., Jastrow, J.D., Schadt, C.W., Wullschleger, S.D., 2013. Variation in root architecture among switchgrass cultivars impacts root decomposition rates. Soil Biology \& Biochemistry 58, 198-206.

Desjardins, T., Andreux, F., Volkoff, B., Cerri, C.C., 1994. Organic carbon and 13 C contents in soils and soil size-fractions, and their changes due to deforestation and pasture installation in eastern Amazonia. Geoderma 61, 103-118.

Fargione, J., Hill, J., Tilman, D., Polasky, S., Hawthorne, P., 2008. Land clearing and the biofuel carbon debt. Science 319, 1235-1238.

Frank, A.B., Berdahl, J.D., Hanson, J.D., Liebig, M.A., 2004. Biomass and carbon partitioning in switchgrass. Crop Science 44, 1391-1396

Garten, C.T., 2012. Review and Model-Based Analysis of Factors Influencing Soil Carbon Sequestration Beneath Switchgrass (Panicum virgatum). Bioenergy Research 5, 124-138.

Garten, C.T., Brice, D.J., Castro, H.F., Graham, R.L., Mayes, M.A., 2011. Response of “Alamo" switchgrass tissue chemistry and biomass to nitrogen fertilization in West Tennessee, USA. Agriculture, Ecosystems, and Environment 140, 289-297.

Garten, C.T., Smith, J.L., Tyler, D.D., Amonette, J.E., Bailey, V.L., Brice, D.J., Castro, H.F., Graham, R.L., Gunderson, C.A., Izaurralde, R.C., Jardine, P.M., Jastrow, J.D., Kerley, M.K., 
Matamala, R., Mayes, M.A., Metting, F.B., Miller, R.M., Moran, K.K., Post, W.M., Sands, R.D., Schadt, C.W., Phillips, J.R., Thomson, A.M., Vugteveen, T., West, T.O., Wullschleger, S.D., 2010. Intra-annual changes in biomass, carbon, and nitrogen dynamics at 4-year old switchgrass field trials in west Tennessee, USA. Agriculture Ecosystems \& Environment 136, 177-184.

Garten, C.T., Wullschleger, S.D., 2000. Soil carbon dynamics beneath switchgrass as indicated by stable isotope analysis. Journal of Environmental Quality 29, 645-653.

Gentile, R., Vanlauwe, B., Chivenge, P., Six, J., 2011a. Trade-offs between the short- and longterm effects of residue quality on soil C and $\mathrm{N}$ dynamics. Plant and Soil 338, 159-169.

Gentile, R., Vanlauwe, B., Six, J., 2011b. Litter quality impacts short- but not long-term soil carbon dynamics in soil aggregate fractions. Ecological Applications 21, 695-703.

Gerzabek, M.H., Haberhauer, G., 2001. Soil organic matter pools and carbon-13 natural abundances in particle-size fractions of a long-term agricultural field experiment receiving organic amendments. Soil Science Society of America Journal 65, 352-358

Goebel, M., Hobbie, S.E., Bulaj, B., Zadworny, M., 2011. Decomposition of the finest root branching orders: linking belowground dynamics to fine-root function and structure. Ecological Monographs 81, 89-102

Grandy, A., Neff, J., 2008. Molecular C dynamics downstream: the biochemical decomposition sequence and its impact on soil organic matter structure and function. The Science of the Total Environment 404, 297-307. 
Groleau-Renaud, V., Plantureux, S., Guckert, A., 1998. Influence of plant morphology on root exudation of maize subjected to mechanical impedance in hydroponic conditions. Plant and Soil 201, 231-239.

Gude, A., Kandeler, E., Gleixner, G., 2012. Input related microbial carbon dynamic of soil organic matter in particle size fractions. Soil Biology and Biochemistry 47, 209-219.

Guo, D.L., Mitchell, R.J., Hendricks, J.J., 2004. Fine root branch orders respond differentially to carbon source-sink manipulations in a longleaf pine forest. Oecologia 140, 450-457.

Guo, D., Li, H., Mitchell, R.J., Han, W, Hendricks, J.J., 2008a. Fine root heterogeneity by branch order: exploring the discrepancy in root turnover estimates between minirhizotron and carbon isotopic methods. New Phytologist 177, 443-456.

Guo, D., Mitchell, R.J., Withington, J.M., Fan, P.P., 2008b. Endogenous and exogenous controls of root life span, mortality and nitrogen flux in a longleaf pine forest: root branch order predominates. Journal of Ecology 96, 737-745.

Hassink, J., Whitmore, A.P., Kubat, J., 1997. Size and density fractionation of soil organic matter and the physical capacity of soils to protect organic matter. European Journal of Agronomy 7, 189-199.

Jaeger, C.H., Lindow, S.E., Miller, S., Clark, E., Firestone, M.K., 1999. Mapping of sugar and amino acid availability in soil around roots with bacterial sensors of sucrose and Tryptophan. Applied and Environmental Microbiology 65, 2685-2690. 
Jastrow, J.D., Amonette, J.E., Bailey, V.L., 2007. Mechanisms controlling soil carbon turnover and their potential application for enhancing carbon sequestration. Climatic Change 80, 5-23.

Jobbagy, E.G., Jackson, R.B., 2000. The vertical distribution of soil organic carbon and its relation to climate and vegetation. Ecological Applications 10, 423-436.

Jolivet, C., Arrouays, D., Lévèque, J., Andreux, F., Chenu, C., 2003. Organic carbon dynamics in soil particle-size separates of sandy Spodosols when forest is cleared for maize cropping. European Journal of Soil Science 54, 257-268.

Jones, M.B., Donnelly, A., 2004. Carbon sequestration in temperate grassland ecosystems and the influence of management, climate and elevated CO(2). New Phytologist 164, 423-439.

Kong, A.Y.Y., Six, J., 2010. Tracing Root vs. Residue Carbon into Soils from Conventional and Alternative Cropping Systems. Soil Science Society of America Journal 74, 1201-1210.

Kuzyakov, Y., Friedel, J.K., Stahr, K., 2000. Review of mechanisms and quantification of priming effects. Soil Biology and Biochemistry 32, 185-1498.

Lal, R., Kimble, J.M., 1997. Conservation tillage for carbon sequestration. Nutrient Cycling in Agroecosystems 49, 243-253.

Lal, R, 2004a. Soil carbon sequestration impacts on global climate change and food security. Science 304, 1623-1627.

Lal, R., 2004b. Soil carbon sequestration to mitigate climate change. Geoderma 123, 1-22. 
Lojewski, N.R., Fischer, D.G., Bailey, J.K., Schweitzer, J.A., Whitham, T.G., Hart, S.C., 2012. Genetic components to belowground carbon fluxes in a riparian forest ecosystem: a common garden approach. New Phytologist 195, 631-639.

Lynd, L.R., Cushman, J.H., Nichols, R.J., Wyman, C.E., 1991. Fuel ethanol from cellulosic biomass. Science 251, 1318-1323.

Ma, Z., Wood, C.W., Bransby, D.I., 2000. Soil management impacts on soil carbon sequestration by switchgrass. Biomass and Bioenergy 18, 469-477.

Madritch, M.D., Hunter, M.D., 2002. Phenotypic diversity influences ecosystem functioning in an oak sandhills community. Ecology 83, 2084-2090.

Matamala, R., Jastrow, J.D., Miller, R.M., 2008. Temporal changes in C and N stocks of restored prairie: implications for C sequestration strategies. Ecological Applications 18, 1470-1488.

McDougall B.M., 1968. The exudation of $\mathrm{C}^{14}$-labelled substances from roots of wheat seedlings. Transactions of the 9th Congress International Soil Science, Adelaide 3, 647-655.

McLaughlin, S.B., Kszos, L.A., 2005. Development of switchgrass (Panicum virgatum) as a bioenergy feedstock in the United States. Biomass \& Bioenergy 28, 515-535.

McLaughlin, S.B., Ugarte, D., Garten, C.T., Lynd, L.R., Sanderson, M.A., Tolbert, V.R., Wolf, D.D., 2002. High-value renewable energy from prairie grasses. Environmental Science \& Technology 36, 2122-2129. 
Nguyen, C., 2003. Rhizodeposition of organic C by plants: mechanisms and controls. Agronomie 23, 375-396.

Norby, R.J., Jackson, R.B., 2000. Root dynamics and global change: seeking an ecosystem perspective. New Phytologist 147, 3-12.

Norby, R.J., O'Neill, E.G., Hood, W.G., Luxmoore, R.J., 1987. Carbon allocation, root exudation and mycorrhizal colonization of Pinus echinata seedlings grown under $\mathrm{CO}(2)$ enrichment. Tree Physiology 3, 203-210.

Nottingham, A.T., Griffiths, H., Chamberlain, P.M., Stott, A.W., Tanner, E.V.J., 2009. Soil priming by sugar and leaf-litter substrates: A link to microbial groups. Applied Soil Ecology 42, 183-190.

O'Brien, S., Jastrow, J., Grimley, D., Gonzalez-Meler, M., 2010. Moisture and vegetation controls on decadal-scale accrual of soil organic carbon and total nitrogen in restored grasslands. Global Change Biology 16, 2573-2588.

O’Brien, S., Jastrow, J., McFarlane, K., Guilderson, T., Gonzalez-Meler, M., 201. Decadal cycling within long-lived carbon pools revealed by dual isotopic analysis of mineral-associated soil organic matter. Biogeochemistry 112, 111-125.

Paterson, E., Sim, A., 1999. Rhizodeposition and C-partitioning of Lolium perenne in axenic culture affected by nitrogen supply and defoliation. Plant and Soil 216, 155-164.

Paustian, K., Six, J., Elliott, E.T., Hunt, H.W., 2000. Management options for reducing CO2 emissions from agricultural soils. Biogeochemistry 48, 147-163. 
Pearson R., Parkinson D., 1961 The sites of excretion of ninhydrin-positive substances by broad bean seedlings. Plant and Soil 13, 391-396.

Piñeros, M.A., Magalhaes, J.V., Alves, V., 2002. The physiology and biophysics of an aluminum tolerance mechanism based on root citrate exudation in maize. Plant Physiology 129, 1194-1206

Post, W.M., Kwon, K.C., 2000. Soil carbon sequestration and land-use change: processes and potential. Global Change Biology 6, 317-327.

Rasse, D.P., Rumpel, C., Dignac, M.F., 2005. Is soil carbon mostly root carbon? Mechanisms for a specific stabilisation. Plant and soil 269, 341-356.

Rees, R.M., Bingham, I.J., Baddeley, J.A., Watson, C.A., 2005. The role of plants and land management in sequestering soil carbon in temperate arable and grassland ecosystems. Geoderma 128, 130-154.

Rovira A.D., 1969. Plant root exudates. Botanical Reviews 35, 35-57.

Schmer, M.R., Vogel, K.P., Mitchell, R.B., Perrin, R.K., 2008. Net energy of cellulosic ethanol from switchgrass. Proceedings of the National Academy of Sciences of the United States of America 105, 464-469.

Schroth, M.N., Snyder, W.C., 1962. Exudation patterns from bean seeds and hypocotyls and their effects on Fusarium solanii f. phaseoli (Abstr.). Phytopathology 52, 751. 
Schweitzer, J.A., Bailey, J.K., Rehill, B.J., Martinsen, G.D., Hart, S.C., Lindroth, R.L., Keim, P., Whitham, T.G., 2004. Genetically based trait in a dominant tree affects ecosystem processes. Ecology Letters 7, 127-134.

Six, J., Conant, R.T., Paul, E.A., Paustian, K., 2002. Stabilization mechanisms of soil organic matter: Implications for C-saturation of soils. Plant and Soil 241, 155-176.

Soussana, J.F., Tallec, T., Blanfort, V., 2010. Mitigating the greenhouse gas balance of ruminant production systems through carbon sequestration in grasslands. Animal 4, 334-350.

Tierney, G.L., Fahey, T.J., 2002. Fine root turnover in a northern hardwood forest: a direct comparison of the radiocarbon and minirhizotron methods. Canadian Journal of Forest Research 32, 1692-1697.

Tilman, D., Hill, J., Lehman, C., 2006. Carbon-negative biofuels from low-input high-diversity grassland biomass. Science 314, 1598-1600.

Torn, M., Kleber, M., Zavaleta, E., Zhu, B., Field, C., Trumbore, S., 2013. A dual isotope approach to isolate soil carbon pools of different turnover times. Biogeosciences 10, 8067-8081.

Van Kessel, C., Boots, S., de Graaff, M., Harris, D., Blum H., Six, J., 2006. Total soil C and N sequestration in a grassland following 10 years of free air $\mathrm{CO} 2$ enrichment. Global Change Biology 12, 2187-2199

Weaver, J.E., Darland, R.W., 1949. Soil-root relationships of certain native grasses in various soil types. . Ecological Monographs 19, 305-338. 
Wells, C.E., Eissenstat, D.M., 2001. Marked differences in survivorship among apple roots of different diameters. Ecology 82, 882-892.

Whitham, T.G., Bailey, J.K., Schweitzer, J.A., Shuster, S.M., Bangert, R.K., Leroy, C.J., Lonsdorf, E.V., Allan, G.J., DiFazio, S.P., Potts, B.M., Fischer, D.G., Gehring, C.A., Lindroth, R.L., Marks, J.C., Hart, S.C., Wimp, G.M., Wooley, S.C., 2006. A framework for community and ecosystem genetics: from genes to ecosystems. Nature Reviews Genetics 7, 510-523.

Wu, L., McGechan, M.B., McRoberts, N., Baddeley, J.A., Watson, C.A., 2007. SPACSYS: Integration of a 3D root architecture component to carbon, nitrogen and water cycling-model description. Ecological Modelling 200, 343-359.

Wynn, J., Harden, J., Fries, T., 2006. Stable carbon isotope depth profiles and soil organic carbon dynamics in the lower Mississippi Basin. Geoderma 131, 89-109.

Xu, J.G., Juma, N.G., 1994. Relations of shoot-C, root-C and root length with root-released-C of 2 barley cultivars and the decomposition of root-released-C in soil. Canadian Journal of Soil Science 74, 17-22. 
Table 1. Fraction $\% \mathrm{C}$ for switchgrass cultivars at $0-10,10-20$, and $20-30 \mathrm{~cm}$ depths. Values are means \pm SE $(n=4)$. Lowercase letters denote significant differences between cultivars. The significance threshold was $\alpha=0.05$.

Table 2. $\delta^{13} \mathrm{C}$ signatures for bulk soil and individual soil fractions from the switchgrass cultivars and adjacent $C_{3}$ grassland at 0-10, 10-20, and 20-30 cm depths. Values are means $\pm S E(n=4)$. 
Figure 1. Total soil C content (1a, 1b, 1c), and switchgrass-derived soil C content (1d,1e, 1f) in Coarse Particulate Organic Matter (CPOM), Fine Particulate Organic Matter (FPOM), silt, and clay fractions for switchgrass cultivars at 0-10, 10-20, and 20-30 cm depths. Values are means $\underline{ \pm}$ SE $(n=4)$.

Figure 2. Correlations between specific root length and switchgrass-derived $\mathrm{C}$ at $0-10 \mathrm{~cm}$ depth with and without a potential outlier. 
Total soil C

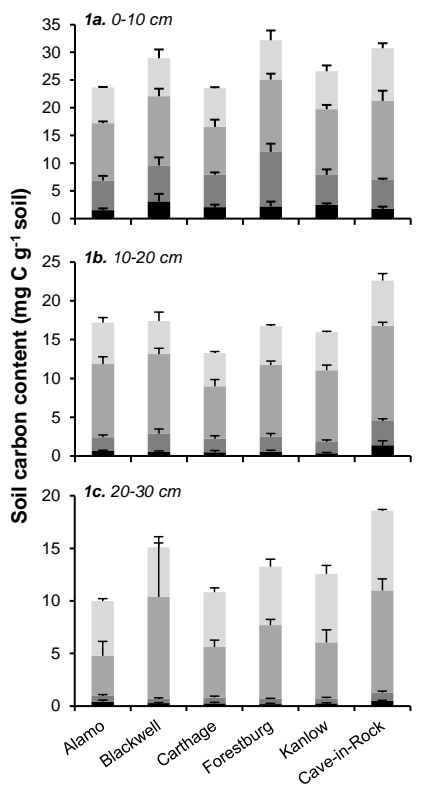

Switchgrass derived soil C
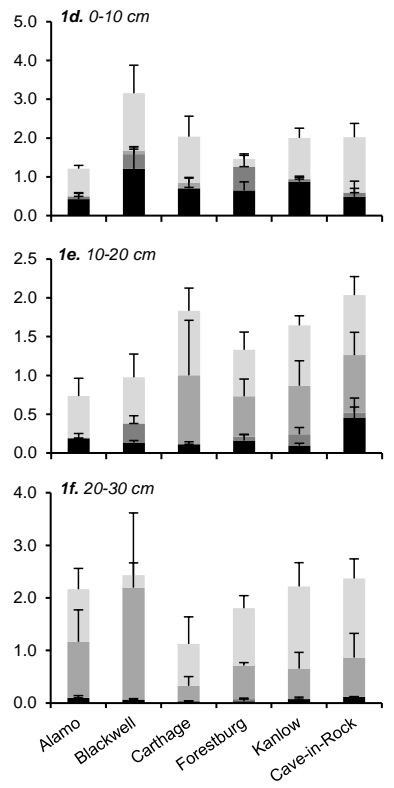

Figure 1 


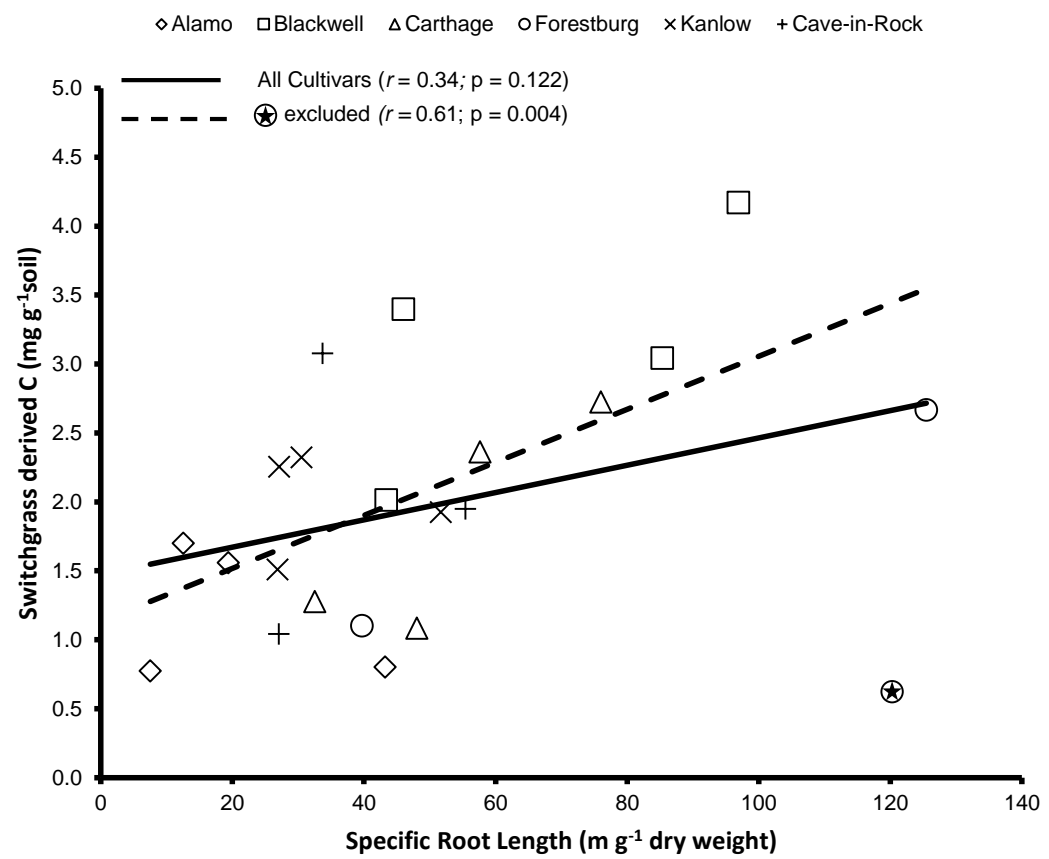

Figure 2 